\title{
KIRAETI / ČITANJA KUR'ANA (QIRA'AT QUR'ANIYYA)
}

\section{Sažetak}

Muhammed Asad (Leopold Weiss, 1900-1990.), revertit u islam, jedan je od brojnih mislilaca koji su umnogome obilježili mišljenje zapadnjačkih muslimana tokom druge polovine XX. stoljeća. Pored ostalih, najznačajnije Asadovo djelo je prevod $i$ komentar Kur'ana na engleskom jeziku pod nazivom The Message of the Qur'an (Poruka Kur'ana). U prvom djelu ovog rada bavimo se pitanjem važnosti poznavanja kiraeta $u$ islamskim naukama. Drugi dio našeg rada ilustruje Asadovo oslanjanje na kiraete u njegovim prijevodnim riješenjima kur'anskih ajeta.

Ključne riječi: Kiraeti, Muhammed Asad, Poruka Kur'ana, prijevodna rješenja

\section{Uvod}

Kiraeti su viševrsna izgovaranja kur'anskih riječi, a prenesena su putem vjerodostojnih hadisa poslanika Muhammeda, a.s. To su leksičke, fonetske i ostale lingvističke forme koje je Allah dž. š., dozvolio tokom učenja Kur'ana- da bi se ljudima olakšalo. ${ }^{1}$

Sedam načina čitanja Kur'ana ( $s e b^{\prime} a$ ahruf) i današnjih sedam kur'anskih čitanja (Qira'at qur'aniyya) dovelo je mnoge u zabunu da pomisle kako nema nikakve razlike između ove dvije vrste čitanja. Allah je objavio Kur'an na sedam načina čitanja a kur'anska čitanja koja nisu ograničena na broj sedam - prema vjerodostojnom hronološkom nizu prenosilaca, odobrio je Božiji Poslanik. Ipak, današnja vjerodostojna čitanja Kur'ana povezana su na neki od načina

\footnotetext{
${ }^{1}$ Ez-Zerkeši, da bi definirao kiraete, pravi razliku između njih i Kur'ana: 'Kur'an je kaže on - Objava koja je poslana Muhammedu, s.a.w.s., na najjasniji način i u i'džazu, a kiraeti su različite artikulacije Objave koje su registrirane u zapisanim harfovima i načinima manifestirane $\mathrm{u}$ takhfifu (upotrebi suglasnika bez udvajanja), tethqilu (udvajanju konsonanata)“ (El-Burhan..., I, 318). El-Džezeri, kaže: „Kiraeti su nauka o načinima izgovora riječi u Kur'anu i razlika među njima koje su prenesene predajom“" (Mundžidu'l-muqri’ in, 3).
} 
sa sedam načina s tim da postoji mimoilaženje među ulemom o vrsti te povezanosti. $^{2}$

Prema jednome mišljenju, današnja kur'anska čitanja nastala su iz svih „sedam načina“ čitanja. Prema drugome mišljenju, ona su nastala samo iz jednog načina. Prema posebnome mišljenju - koje se temelji na njihovom nastanku iz jednog načina, ova kur'anska čitanja su nastala iz onoga načina prema kojem je Vjerovjesnik učio Kur'an posljednji put pred melekom Džibrilom. ${ }^{3}$ Naime, prema vjerodostojnim hadisima, melek Džibril je svakog ramazana imao susret s Božijim Poslanikom i s njim sravnjivao Kur'an. $O$ tome Aiša prenosi od Fatime: „Vjerovjesnik, a. s., mi je tajno rekao: 'Džibril me je preslušavao Kur'an svake godine, a ove me je godine preslušavao dva puta. Po tome vidim da mi se približio kraj““ (Buhari).

Prema drugačijem mišljenju, sva kur'anska čitanja u saglasnosti su s Osmanovim mushafom koji je napisan prema jednom načinu, ali bez tačaka za označavanje konsonanata i vokala tako da se mogao čitati i na ostalih šest načina. Prema ovakvom tumačenju, Osmanov mushaf sadrži svih sedam načina.

\footnotetext{
${ }^{2}$ Dozvola da se Kur'an uči na harfove Arapima je pružala olakšicu budući da im je učenje Kur'ana na jednom dijalektu pričinjavalo poteškoću. Bili su neuki, neznatan broj je znao pisati. Pošto je situacija bila takva da su pripadnici jednog plemena teško usvajali dijalekat drugog plemena, omogućeno im je čitanje Kur'ana prema vlastitim dijalekatskim formama, s tim što su značenje i smisao kur'anskoga izraza morali ostati nepromijenjeni. Tako je potrajalo sve dok se većina nije opismenila i prilagodila svoj govor Poslanikovom, s.a.v.s., govoru. Kada su došli u priliku da lakše usvajaju, pamte i artikuliraju kur'anske riječi, dozvola da uče Kur'an shodno ranijoj olakšici bila im je uskraćena, smatra Et-Tahavi (Vidi: Al-Qurtubi, Al-Gami' li 'ahkami 'l-Qur 'an, Daru'l-hadis, Kairo, izd. II, 1996., sv. I, str. 59.).

3 Al-Qaysi, Maki b. Abu Talib (1977), Al-Ibana 'an ma'ni al-qira'at, Dar Nahda Misr, al-Qahira, 32-36.
} 
Postoji i mišljenje da sedam kur'anskih čitanja predstavlja uglavnom fonološke razlike u čitanjima Kur'ana ${ }^{4}$, a sedam načina predstavlja mogućnost čitanja Kur'ana na sedam dijalekata. ${ }^{5}$

Muhammed Asad u mnogim svojim komentarima ajeta navodi različita kur'anska čitanja. No prije nego što navedemo neke primjere koje nam Asad daje, razmatrat ćemo kiraete sa tri aspekta:

- koji su izvori nastanka kur'anskih čitanja?

- zašto su značajna kur'anska čitanja u komentarima Kur'ana?

- kakve su refleksije kur'anskih čitanja u fikhu?

U pogledu izvora nastanka kur'anskih čitanja među muslimanskim naučnicima postoje različita mišljenja, a uglavnom pretežu dva osnovna. Prema jednome, izvor je Objava, dok, prema drugima, ona to nije. Oni koji smatraju da je Objava izvor čitanja, samim tim smatraju da sva kur'anska čitanja predstavljaju dio Kur'ana. Prema ovim učenjacima, Kur'an je, sa svojim čitanjima, i u formalnom i u značenjskom smislu od Allaha objavljen. Niko nema pravo mijenjati ništa od toga, čak ni slovo; to pravo nisu imali ni Džibril ni Poslanik, a.s.

4 Fonološke razlike u smislu dužine vokala, izgovor konsonanata s vokalom ili sukunom, mogućnost premještanja vokala na prethodni konsonant sa sukunom, različita fleksija riječi.

${ }^{5} \mathrm{U}$ teoriji nauke o kiraetima, kao i u raznorodnoj tefsirskoj literaturi koja tretira pitanje kiraeta, navode se brojna mišljenja o aspektima i razlozima različitih čitanja kur'anskog teksta. Sve to, dakako, u tijesnoj je vezi s tumačenjem hadisa o sedam harfova. Dijalekatske raznolikosti $\mathrm{u}$ arapskome jeziku u vrijeme objavljivanja Kur'ana, prema mišljenju mnogih eminentnih islamskih učenjaka, ključni su aspekt u razumijevanju kako prirode kiraetskih divergencija, tako i mudrosti Božije olakšice da se Kur'an uči na sedam harfova. Dijalekatske razlike među kiraetima moguće je reducirati na četiri osnove: derivacijsku, morfološku, fonetsku i leksičku. Poznato je da svaki govor o nastanku i razvoju kiraetske nauke počinje od hadisa o sedam harfova. Značenje sintagme „sedam harfova“ bilo je predmet iscrpnih rasprava među islamskim učenjacima. Jedno od najdominantnijih mišljenja jeste da sedam harfova predstavlja sedam arapskih dijalekata na kojima je objavljen Kur'an. (Vidi: Dr. hfz. Dževad Šošić, Dijalekatske razlike među kira'etima, Zbornik radova, godina XXIX, 2010, br. 14.) 
Prema drugoj grupi naučnika, koji smatraju da izvor kur'anskih čitanja nije Objava, već su to - prema jednima - arapski dijalekti, prema drugima - naučni napor čitača Kur'ana te - prema trećima - arapsko pismo kojim su napisani Osmanovi mushafi.

Ibn Atijje ${ }^{6}$ kaže da Poslanikov iskaz "Kur'an je objavljen na sedam harfova" znači da su u njegovu jezičku strukturu ukomponovani dijalekti sedam arapskih plemena kojima je objavljen Kur'an: nekada je značenje izraženo dijalektom plemena Kurejša, nekada dijalektom Huzejla, nekada drugim dijalektom, u zavisnosti od toga koji izraz je rječitiji i sadržajniji. "Zar ne primjećujete", nastavlja Ibn Atijje, "da glagol fetare u drugim dijalektima, za razliku od dijalekta Kurejša, znači 'ibtede'e? Taj glagol je upotrijebljen u kur'anskom tekstu, ali Ibn Abbasu nije bila jasna njegova etimološka pozadina dok se pred njim nisu pojavila dvojica beduina koji su su se sporili oko bunara. Jedan od njih je uzviknuo: 'Ja sam ga sagradio (ene fetartuhu)', pa Ibn Abbas kaže: 'Tada sam shvatio riječ Uzvišenog.'“67

Pa ipak ni zagovornici tog mišljenja nisu se mogli usaglasiti o imenima plemena, nosioca tih dijalekata. Jedni smatraju da su to dijalekti plemena: Kurejš, Huzejl, Sekif, Hevazin, Kinane, Temim i Jemen; drugi smatraju da su to: Kurejš, Huzejl, Temim, El-Ezd, Rebi‘a, Hevazin i Sa'd b. Bekr; treći kažu da je riječ o sedam narječja Mudara navodeći kao dokaz izjavu Osmana, r. a.: "Kur'an je objavljen na jeziku Mudara."

Evo nekih primjera različitih dijalekatskih derivacija istih leksičkih osnova:

A) glagol yuběšsiruke u 39. ajetu sure Ali Imran:

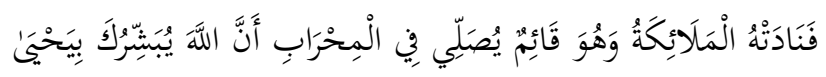

I meleci ga - dok je on klanjao stojeći u hramu - zovnuše: „Allah ti radosnu vijest zbilja za Jahjaa šalje...

${ }^{6}$ Ebu-Muhammed Abdu'l-Hakk b. Atijja andalužanski pravnik malikijske škole, muhaddis, mufessir i arapski lingvist. Obnašao dužnost kadije u ondašnjem gradu Almeriji. Umro 481. godine po H.

${ }^{7}$ Vidjeti tumačenje 11. ajeta sure Eš-Šura u Kurtubijevom tefsiru. 
Hamza i El-Kisai su navedeni glagol čitali s fethom na ja, sukunom na ba i dammom na šinu; ostali su ga čitali s dammom na ja, fethom na ba i kesrom na geminiranom šinu. Riječ je o dva poznata dijalekta: geminacija (tešdid) je hidžaska varijanta, a njegovo izostavljanje varijanta plemena Tihame. $^{8}$

Dva kiraeta predstavljaju dvije glagolske vrste (prvu i drugu) sa istim značenjem, tj. „obradovati“", „obveseliti“, „donijeti radosnu vijest“. Oblik bez geminacije izveden je od riječi el-bišr, a označava „, nasmijanost“, „veselost“, „radost“, ,,vedrinu“. Izvedena imenica glasi el-bišare i el-bušare, s dammom i kesrom na ba, dok je geminirani oblik izveden od riječi et-tebšir. Imenice el-bišr i et-tebšir u semantičkoj osnovi ukazuju na vijest koja svome recipijentu mijenja izraz lica i daje mu radost. 9

B) riječ er-r'ub u 151. ajetu sure Ali-Imran:

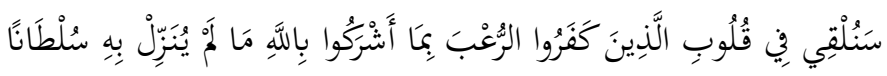

Mi ćemo uliti strah u srca onih koji neće da vjeruju zato što druge Allahu ravnim smatraju, o kojima On nije objavio ništa...

Riječ er-ru 'b (određenu ili neodređenu) Ibn Amir, El-Kisai, Ebu Džafer i Jakub čitali su s dammom na 'ajnu shodno hidžaskoj dijalekatskoj varijanti; ostali su tu imenicu čitali sa sukunom na 'ajnu prema varijanti plemena Temim, Esed i Kajs. U pitanju su dva infinitivna oblika sa istim značenjem -,„strah“ . Neki kažu da je oblik sa sukunom osnova, a da je dammaupotrijebljena radi vokalne harmonije slično kao kod riječi 'usr, jusr/usur i jusitr. Neki, pak, tvrde da je oblik s dammom osnova, a da je sukun unotriieblien radi lakšeg izgovora, kao što je slučaj s imenicom: er-rusul i er-rusl. ${ }^{10}$

Svrha kiraeta je da se svim Arabljanima olakša ne samo izgovor nego i razumijevanje Kur'ana, kako navodi Ibn Hadžer el-Askalani. Poslanik, a.s., je bio taj koji je sve njih usmjeravao (u) raznovrsnosti kiraeta budući da su oni imali usaglašeno mišljenje oko osnovnih smislova

\footnotetext{
${ }^{8}$ Isto, sv. I, str. 121.

9 Vidi: Muhammad Muhaysin, Al-Muqtabas mine'l-lahagati'l-'arabiyya wa'lqur'aniyya, Mekteba Al-Kulliyyat al-azhariyya, Kairo, 1979., str. 70.

${ }^{10}$ Isto, 138.
} 
Kur'ana. Poslanik, a.s., jeste dozvolio upotrebu različitih kiraeta ali oni (ashabi) nisu mogli da ih upotrebljavaju proizvoljno, da svako po svome nahođenju promijeni neku riječ svojom, dijalekatskom sinonimnom riječju. Oni su mogli da upotrijebe određenu kiraetsku varijantu samo ukoliko su je čuli od Poslanika, a.s. ${ }^{11}$

Što se tiče naučnog napora čitača Kur'ana (al-idžtihad al-qurra') kao izvora nastanka kur'anskih čitanja, taj stav zagovara vrlo mali broj muslimanskih naučnika.

Stav prema kome je pismo Osmanovih mushafa bez znakova za vokale i dijakritičkih tačaka na konsonantima izvor različitih kur'anskih čitanja zastupaju uglavnom neki orijentalisti, prije svih Ignac Goldziher (1850.-1921.). Međutim, kur'ansko pismo Osmanovih mushafa, prema muslimanskim naučnicima, pomaže razumijevanju vjerodostojno tradiranih kur'anskih čitanja. Odsustvo tačaka na konsonantima i oznaka za vokale u Osmanovim mushafima dopušta da se jedna riječ može čitati na više načina. Osmanov mushaf daje im istovremeno i legitimnost zbog njihovog uporišta u njemu. Zbog toga $\mathrm{i}$ jeste jedan od glavnih uvjeta prihvatljivosti kur'anskih čitanja njihova saglasnost $\mathrm{s}$ Osmanovim mushafom.

Sva čitanja Kur'ana su sačuvana u vjerodostojnim i višebrojnim nizovima prenosilaca u usmenoj formi još prije sakupljanja kur'anskoga teksta u jednu knjigu (mushaf), naročito prije Osmanovog mushafa. Iz ovoga možemo zaključiti da kur'anska čitanja nisu uvjetovana pismom nego vjerodostojnim predajama. Prema ovom zaključku jedna grupa muslimanskih učenjaka tvrdi da karakter tadašnjeg arapskoga pisma nije nikako mogao biti razlog nastanka kur'anskih čitanja.

Vratimo se još kratko na pitanje nastanka kiraeta. Sva ova oprečna mišljenja o nastanku današnjih kiraetskih čitanja ne spore da su kur'anska čitanja/učenja koja danas postoje nastala u vrijeme poslanika Muhammeda, a. s., da ih je on odobrio, njegovi drugovi registrirali, halifa Osman u jednoj knjizi (mushafu) potvrdio, a naučnici poslije njih utvrdili stepen vjerodostojnosti. Naučnici su naučno utemeljili, uredili i odstranili sva ona čitanja za koja se nije moglo utvrditi da imaju sigurnu vezu sa Vjerovjesnikom. Ovdje ističemo još jednom da

${ }^{11}$ Asqalani, Fethu'l-bari, X, 402. 
kur'anska čitanja/učenja i sedam načina predstavljaju samo dopuštenje različitog čitanja/učenja nekih riječi i konstrukcija u Kur'anu, a ne uključuju pisani tekst Kur'ana koji je još za života Božijeg Poslanika utvrđen tako što je pisan onako kako ga je on diktirao.

Iz gore izloženog vidimo da se vrlo rano pristupilo sakupljanju i kodifikaciji kur'anskih čitanja. Naučnici su odredili posebne uvjete za status pravilnog kur'anskog čitanja/učenja: sva ona morala su biti u saglasnosti sa Osmanovim mushafom; određeni kiraet mora lančanim putem biti vezan za Muhammeda, a. s. Kasnije je pridodat i uvjet saglasnosti sa pravilima arapskoga jezika. Prema navedenim uvjetima, Ibn Mudžahid (u. 324/936) je od dvadeset i pet poznatih čitanja ${ }^{12}$ odabrao poznatih sedam čitanja (qira'at $s a b^{\prime} a$ ) koja su se prakticirala u Hidžazu, Iraku i Šamu. ${ }^{13}$

Najveće razlike među kur'anskim čitanjima manifestiraju se na fonološkom nivou $u$ različitom artikuliranju glasova, dužini samoglasnika, upotrebi hemzeta i drugih glasovnih promjena. Kur'anska čitanja prema ovim naučnicima odslikavaju jezičku stvarnost Arapa. Prema tome, postojanje mnogih dijalekata predstavlja osnovni izvor za izučavanje kur'anskih čitanja/učenja. ${ }^{14}$

${ }^{12}$ Ebu-Ubejd el-Kasim b. Sellem (u. 224/839) je sakupio dvadeset i pet čitanja.

13 Ibn Al-Džazari, Abu al-Hajr Muhammad b. Muhammad al-Dimaški, Al-Našr fi alqira'at al-'ašr, I, Ii, Dar al-Kutub al-ilmiyya, Bayrut, 34.

14 Već smo navodili neke primjere. Evo još nekih kur'anskih ajeta sa različitim dijalekatskim izgovorima:

1. u riječima Uzvišenog innallaahe laa jestahjii en jadribe methelen(El-Beqare, 26), većina izgovara jestahjije, (sa dva ja'a) a perfekt jestahjaa. Međutim, Ibn Kethir i Jakub izgovaraju jestahjii kako se izgovara u temimskom dijalektu;

2. u riječima Uzvišenog we laa jeltefit minkum ehadun illemre'etek (Hud, 81) u hidžaskom dijalektu imre'e se izgovara u akuzativu i tog izgovora se drži većina, dok se u temimskom dijalektu ona izgovara u nominativnoj formi;.

Primjer različitih dijalekatskih izgovora u ajetima koji sadrže pravne propise (ajatu'lahkam): laa tuqaatiluuhum 'inde'l-Mesdžidi'l-haraami hattaa juqaatiluukum fiih (ElBeqare, 191), većina izgovara tuqaatiluuhum, a Hamza i Kisa'i: taqtuluuhum.

U oba se kiraeta zabranjuje ratovanje sa mušricima u prostoru Mesdžidil-harama sve dok oni ne budu započeli borbu. Kiraet većine podrazumijeva zabranu napada na njih kada oni izvrše pripreme za napad na muslimane (prije nego oni započnu sa napadom, kako bi se sačuvala svetost ovog mjesta i kako se u njemu ne bi prolijevala krv). 
Vjerodostojne kiraetske verzije su nepresušan izvor koji su koristili mnogi komentatori Kur'ana za otkrivanje brojnih višeslojnih značenja kur'anskih ajeta. Nekada su ta značenja bliska, u drugim slučajevima su različita, ali nikada nisu međusobno kontradiktorna budući da kiraetska višestrukost potječe iz istog izvora, što znači da se ona međusobno argumentira i na određenom semantičkom polju susreće jer ukazuje na jednu veliku Istinu i Poruku.

Kiraeti su posebno važni sa aspekta islamskog prava. Donoseći pravna rješenja, islamski pravnici (fuqaha) koristili su kiraetske verzije u tri pravca:

- na osnovu različitih kiraetskih izgovora donosili su jednoglasna pravna rješenja;

- kiraeti su im poslužili da izvode različite pravne norme imajući u vidu svakodnevne životne okolnosti;

- koristeći kiraetske verzije, islamski pravnici su davali više rješenja o istom pitanju.

Evo jednog primjera.

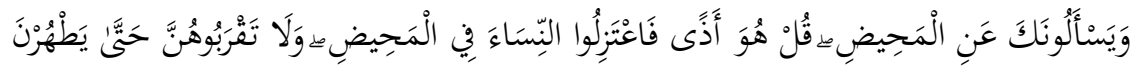

Međutim, Hamzin i Kisaijev kiraet znače zabranu borbe protiv njih samo kada se oni nisu spremili za napad na muslimane pa onda ni muslimanima nije dozvoljeno da se spremaju za napad na neke od njih kako ih ne bi podstakli na ratovanje, dok onaj prvi kiraet sugeriše značenje da jedan dio muslimana bude budan i da zna da će imati pobjedu samo ukoliko se strpe dok ih njihovi neprijatelji ne napadnu, radi čega im Uzvišeni poručuje: fe in qaateluukum faqtuluuhum (,pa ako vas oni napadnu, onda ratujte protiv njih“). A nije rečeno feqaatiluuhum kako bi muslimani shvatili da će im pripasti pobjeda i nadmoć i da, bez njihova napada, muslimani nemaju pravo da povedu rat protiv svojih neprijatelja. Ebus- Sud komentarišući ovaj ajet kaže: „U ovom skretanju na oblik mufa'ile kojim je navedena zabrana (oblik koji podrazumijeva međusobno vršenje radnje, međusobno ratovanje ) krije se poruka da pobjeda traži vremena.“ (Tefsiru Ebi's-Su'ud, I, 157.)

Ponekad se kiraetske razlike jave radi stilskog konciznog izraza (idžaz). Tako se dio 22. ajeta sure El-Hašr (kao i njegovo pojavljivanje u brojnim drugim surama) 'aalimu'l-gajbi we'ššsehaade („Onaj koji poznaje nevidljivi i vidljivi svijet“) može učiti i kao 'allamu'l-gajbi sa dodatnim, još većim značenjem Onoga koji poznaje sve stvari iz nevidljivog i vidljivog svijeta, Sveznajućeg. 
Pitaju te o mjesečnom pranju. Ti reci: To je gadljivo. Od žena u mjesečnom pranju vi podalje! I ne približavajte im se dok se ne očistite... ( El-Bekara, 222).

Pored kiraetske verzije koja je navedena $\mathrm{u}$ datom ajetu koristi se $\mathrm{i}$ verzija jettaherne. Prema prvoj verziji, jathurne (,dok se ne očiste“) ne obavezuje ženu nakon mjesečnog ciklusa da se okupa. Spolni akt je dozvoljen čim prestane krvarenje. Druga kiraetska verzija (jettaherne)obavezuje ženu na kupanje pa je tek tada spolni akt dozvoljen. Ovaj primjer potvrđuje da su vjerodostojne kiraetske verzije poslužile kao argumenti islamskim pravnicima da o istom pitanju donesu dvije ili više pravnih normi. ${ }^{15}$

Poznavanjem kiraeta možemo doći do iznijansiranih značenja kur'anskoga teksta. Evo nekoliko primjera:

a) kiraetska verzija la tus'el -la tes'el

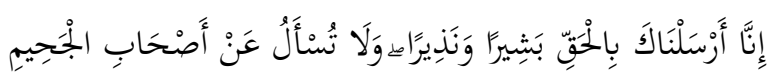

Mi smo tebe poslali s Istinom, da radosne vijesti preneseš i da Opomenu saopćiš! I za stanovnike Pakla nećeš biti pitan! ( El-Bekara, 119).

Imam Nafi koristi izgovorla tes'el (,ne pitaj“), dok ostali imami koriste varijantu la tus'el (,nećeš biti pitan“). Prema Ibn Abbasu, navedeni ajet ima slijedeće značenje:

- ,Muhammede! Poslali smo ti Kur'an i vjeru monoteizma da obraduješ Džennetom one koji budu Allaha vjerovali i da podsjećaš na Džehennem one koji ne budu vjerovali, a ti za njih nećeš odgovornost snositi. Nije ti dozvoljeno da pitaš za stanovnike Džehennema i da za njih oprost moliš‘‘;

- Zamahšeri navodi da je Muhammed, a. s., jednom prilikom rekao: „Da mi je znati šta je sa mojim roditeljima." Kao odgovor na ovu želju objavljen je ajet u kome se Vjerovjesniku zabranjuje da pita za stanje nevjernika i da se za njih moli, niti je njegovo da se o njima brine $\mathrm{i}$ da im važnost pridaje. ${ }^{16}$

b) kiraetska verzija kebir i kesir

\footnotetext{
15 Tuhmaz, Hanefijski fikh, 146-159.

${ }^{16}$ V. El-Keššaf ( komentar ajeta 119 sure El-Bekare).
} 


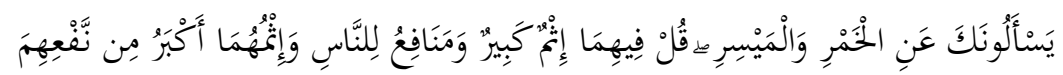

Pitaju te o vinu i kocki. Ti reci: U tome dvome je grijeh veliki a i neke koristi za ljude...! (El-Bekara, 219)

Jedne karije (Hamza i El-Kisa) koriste verziju ismun kesir (,grijesi su mnogobrojni“), a ostali imami i ranije navedenu verziju (ismun kebir). Prema prvom kiraetskom izgovoru (kesir), ovdje se ukazuje na mnogobrojne loše posljedice koje uzrokuje kockanje, pijenje vina i ostalih opojnih pića. Ovi imami uporište za ovaj kiraet traže u hadisu u kojem je Poslanik prokleo deset osoba u vezi sa alkoholom. Drugim kiraetskim izgovoru (kebir) ukazuje se na veličinu i težinu grijeha koji se čini kockanjem i pijenjem vina. Zagovornici ove verzije kažu da u nastavku navedenog ajeta slijedi sintagma ekberu min nef'ihima. Mi ističemo da obje verzije prema pravopisu prvih mushafa imaju istu ortografsku formu, a i njihova značenja su bliska: kockanje i opojna pića su veliki grijeh, a njihove negativne posljedice su mnogobrojne. ${ }^{17}$

S obzirom na tefsirske/komentatorske osobenosti, kiraeti u odnosu na kur'anski tekst mogu imati nekoliko funkcija:

a) proširivanje značenja riječi; ${ }^{18}$

b) otklanjanje nejasnoće u značenju ajeta; ${ }^{19}$

c) diferenciranje posebnog od općeg značenja; ${ }^{20}$

17 Isto.

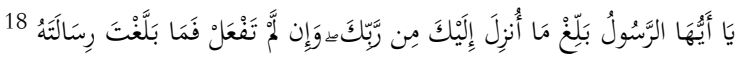

O, Poslaniče, kazuj ono što ti se objavljuje od Gospodara tvoga, - ako ne učiniš, onda nisi dostavio poslanicu Njegovu... ( El-Maida, 67).

Riječ risalet sadrži dva kiraeta: Nafi, Ibn Amir, Šube, Ebu Džafer i Jakub čitali su tu riječ u množini (risalat), a ostali imami u jednini. Kiraet množine ima šire značenje jer upućuje na činjenicu da su prije Muhammeda, a. s., živjeli i djelovali Božiji poslanici te da je svaki od njih primio poslanicu kao izvor vjere, upute, zakona $\mathrm{i}$ moralnih principa. Vjerski obredi i zakoni razlikovali su se od poslanika do poslanika, ali je njihova matrica bila ista. Kiraet jednine uzima u obzir i ističe upravo tu matricu (tewhid) kao osnovu na kojoj počiva vjera i pokornost jednome Stvoritelju.

${ }^{19}$ Pogledati našu napomenu br. 26 kao primjer.

${ }^{20}$ Neke kur'anske riječi imaju općenito značenje, tj. odnose se na mnoštvo likova, stvari ili pojava, ali su u Kur'anu upotrijebljene sa posebnim značenjem. U određenim slučajevima kiraeti mogu poslužiti kao efikasan metod uočavanja takve upotrebe kao 


\section{d) ograničavanje apsolutnih izraza u pojedinim ajetima; ${ }^{21}$ e) pojašnjavanje konciznih kur'anskih izraza. ${ }^{22}$}

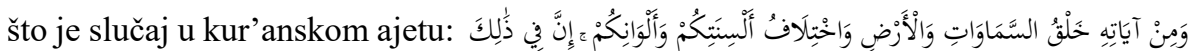
L الَيَاتِ لِلْعَالِمينَ - I jedan od dokaza Njegovih je stvaranje nebesa i Zemlje, i raznovrsnost jezika vaših i boja vaših; to su, zaista, pouke za one koji znaju. (Er-Rum, 22.)

Riječ el-alimin sa fethom na lamu kiraet je svih imama osim Hafsa, Asimovog ravije. Ta riječ ima općenito značenje - odnosi se na sva Allahova stvorenja, na sve vrste svjetova, znanih i neznanih, koji egzistiraju u pojavnom svijetu. Hafsov kiraet elalimin, sa kesrom na lamu, iz te općenitosti izdvaja posebno značenje. Riječ je o razumom obdarenim, učenim ljudima, koji znaju čitati, istraživati, proučavati Božije znakove, dokaze, među koje spadaju i dokazi spomenuti u ajetu.

${ }^{21}$ U nekim kur'anskim ajetima postoje apsolutni izrazi čiji se pojmovni sadržaj, na osnovu valjanog argumenta, ograničava na određeno svojstvo, broj, stanje i sl. U tom smislu, kiraetske varijante mogu poslužiti kao validna argumentacija. Naprimjer:

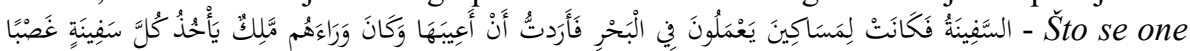
lađe tiče, - ona je vlasništtvo siromaha koji rade na moru, i ja sam je oštetio jer je pred njima bio jedan vladar koji je svaku lađu otimao. (El-Kehf, 79).

Ajet je citiran prema verziji koju primjenjuju imami deset mutevatir kiraeta. Za razliku od te verzije evidentirana je verzija (šazz kira'et) Ibn Abbasa koja odudara od mushafskog pravopisa, a glasi: (...) Ja sam je oštetio jer je pred njima bio jedan vladar koji je svaku ispravnu lađu otimao.

U prvoj, mutevatir verziji, izraz „svaku lađu“ pojmovno je neograničen tako da se može razumjeti kako je spomenuti vladar otimao svaku lađu, bez obzira na njezinu veličinu, izgled i stanje. Međutim, atribut salihat u kiraetu Ibn Abbasa ograničava pojam "lađa" na veoma bitno svojstvo - ispravnost što znači da je vladar otimao samo "ispravne lađe". No i bez tefsirskog pojašnjenja što ga nudi kiraet Ibn Abbasa, ne bi bilo teško zaključiti da je riječ o "ispravnoj lađi” jer Hidrov iskaz u ajetu „I ja sam je oštetio“ jasno upućuje na činjenicu da je vladar otimao samo "ispravne lađe”.

${ }^{22}$ Ranije je kazano da kur'anski izraz, pored ostalog, krasi stilska konciznost. Smisao konciznih ajeta razumije se iz samog konteksta ili je, pak, pojašnjen drugim ajetima kazanim o istoj temi u opširnijoj formi. Kiraetske razlike mogu biti u funkciji takvog

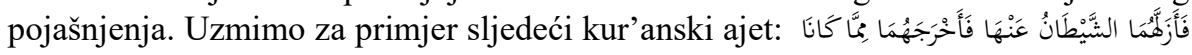
في - I šejtan ih navede da zbog drveta posrnu i izvede ih iz onoga u čemu su bili. ( ElBekare, 36)

Glagol feezelle čitan je na dva kiraeta: sa elifom poslije konsonanta "z" i bez tešdida na lamu - feezale - prema Hamzinom kiraetu. Ostali imami u kiraetima primijenili su verziju suprotno navedenoj, tj. bez elifa, sa tešdidom na lamu kao što je u citiranom ajetu.

Glagol feezale znači: ,ukloniti“, „odstraniti“, ,udaljiti“. Shodno tome značenju, Iblis je "uklonio" Adema, a. s., i Havu sa njihovog mjesta u Džennetu. U tom iskazu postoji 


\section{Kiraeti u Asadovoj Poruci Kur'ana}

Kiraeti u Asadovoj Poruci Kur'ana imaju posebno mjesto i ona nedvojbeno ukazuje na činjenicu da oni nisu stilovi glasovnih varijacija i moduliranja učača Kur'ana, već sastavni dio kur'anskoga jezika, njegove leksičke, morfološke i sintaksičke strukture. Asad, doduše, nije išao u detaljna razmatranja kiraetskih varijanti, odnosno nije izučavao utjecaj kiraeta u tumačenju Kur'ana sa šerijatskopravnog aspekta. ${ }^{23}$ On ih najviše koristi kako bi objasnio proširivanje ili pojašnjavanje značenja nekog ajeta ili eksplikaciju konciznih izraza u Kur'anu. Bez obzira na to, iz primjera koji slijede sasvim je jasno da je razumijevanje kiraeta uvjet za pravilnu interpretaciju većeg dijela kur'anskoga teksta (ustvari, jedna od metoda tumačenja Kur'ana Kur'anom).

$$
\text { وَمَا أُنِْلَ عَلَى الْمَلَكَيْنِ بِبَابِل هَارُوتَ وَمَارُوتَ }
$$

(...) a oni slijede ono što im je sišlo preko dva meleka u Babilonu, Haruta i Maruta (...) $)^{24}$

Asad navodi da je autentično zabilježeno (od strane Taberija, Zamahšerija, Begavija i Razija) kako je veliki Poslanikov ashab Ibn Abbas - kao i nekoliko učenih ljudi slijedeće generacije (poput Hasana el-Basrija, Ebu-Esveda i Ed-Dahhaka) - ovaj ajet čitao kao melikejn koje dolazi u značenju „dva kralja“. Asad ističe da je osobno naklonjen ovom posljednjem kiraetu, ali ipak uzima jedno drugo, općenitije prihvaćeno čitanje koje se prevodi kao „dva meleka“.

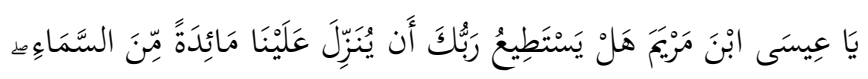

konciznost iz koje se ne doznaje kako se to desilo. Glagol feezelle (kiraet većine imama) sa značenjem „učiniti da poklizne“, „navesti da pogriješi“, „,navratiti na grijeh“... pojašnjava kako je Iblis uspio ostvariti izgon Adema, a. s., i Have iz Dženneta. Prema tom kiraetu Iblis je nagovorio Adema, a. s., i Havu na čin grijeha i neposlušnosti prema Stvoritelju, što je rezultiralo njihovim izgonom iz Dženneta. Navedeni primjer dovoljno govori da razlike među kiraetima ponekad čine komplementarnost u pružanju jasnije vizije onoga o čemu Kur'an kazuje.

${ }^{23}$ Tako, npr., Asad u svome komentaru ne spominje kiraetske varijante u ajetima o gusulu i tejemmumu (4:43), o abdestu (5:6), o postu (2-183 i 184), o krađi (5:38), o hadždžu (2:196), o mjesečnici $(2: 222) \ldots$ O utjecaju kiraeta $s$ tog aspekta vidjeti Dževad Šušić, Kiraeti u tefsiru imama Kurtubija, str. 255-277.

${ }^{24}$ El-Bekare, 101. 
(...) O, Isa, sine Merjemin, da li bi nam mogao tvoj Gospodar spustiti sofru s nebesa? (...) $)^{25}$

U vezi s gornjim ajetom Asad navodi: „Imamo, međutim, siguran dokaz o činjenici da su nekoliko istaknutih Poslanikovih ashaba - Ali, Ibn Abbas, Aiša i Muaz ibn Džebbel - čitali te riječi kao hel testeti Rabbeke, što bi se moglo prevesti kao: 'Bi li ti mogao navesti svog Uzdržavatelja?'،26 Prema Asadu, ovo zadnje čitanje implicira neizvjesnost učenika u pogledu Isaove sposobnosti da postavi gornji zahtjev Bogu. Ovdje napominjemo da je Razi naveo u svome komentaru kako je Aiša, odbijajući prihvatiti više uobičajeno čitanje hel jesteti' Rabbuke (,može li“ ili ,, bi li mogao tvoj Uzdržavatelj“), rekla: „Isaovi učenici su znali nešto bolje nego pitati da li je Bog u stanju nešto učiniti; oni su samo pitali (Isaa): 'Jesi li ti u stanju tražiti od svoga Uzdržavatelja?'“‘

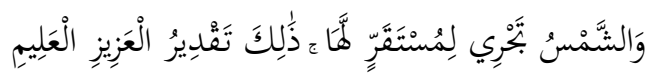

I (oni imaju znak u) Suncu: ono se kreće putanjom svojom - (a) ona je postavljena voljom Svemogućeg, Sveznajućeg. ${ }^{27}$

Asad kaže da je Ibn Mesud čitao ove riječi kao la musteqarre leha, što daje posve novo značenje: „ono se kreće (svojom putanjom) bez ikakvog odmora“, tj. neprestano. ${ }^{28}$ Asad se u ovom slučaju, naravno, oslanja na Zamahšerijev komentar.

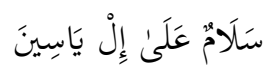

Mir neka je Il'jasu i njegovim sljedbenicima! ${ }^{29}$

Asad kaže da Taberi navodi kako je Abdullah ibn Mes'ud čitao ovaj ajet ovako: „Mir neka bude Idrasinima!“،, što - pored toga što nam daje varijantu ili množinu od Idris („Idris i njegovi sljedbenici“") - daje

\footnotetext{
${ }^{25}$ El-Maida, 112.

${ }^{26}$ Asad, Poruka Kur'ana, 162 (137); ovaj kiraet navodi Taberi, Zamahšeri, Begavi, Razi i Ibn Kesir.

27 Ja-Sin, 38.

${ }^{28}$ Asad, Poruka Kur'ana, 675 (19).

${ }^{29}$ Es-Saffat, 130.
} 
podršku gledištu da su Idris i Il'jas samo dvije oznake jedne te iste osobe, biblijskog Elijaha. ${ }^{30}$

Zanimljivo je da Asad vrlo često u svome prijevodu, nastojeći naći „pravi“ smisao i doći do univerzalne poruke ajeta, koristi različite kiraete. Uzmimo za primjer 19. ajet sure Sebe' koji prevodi ovako:

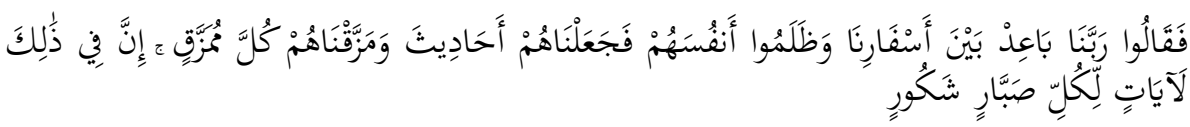

Ali sada bi oni obično rekli: „Drugim je učinio Stvoritelj naš udaljenosti između naših putnih stanica!" - jer oni su bili zgriješili protiv samih sebe. A, konačno, Mi učinismo da postanu (jedna od onih) priča (o nečemu što je davno minulo), i raspršismo ih u bezbrojne ostatke. U tome su, vidi, poruke za sve koji su potpunoo strpljivi $u$ nevolji i koji su duboko zahvalni (Allahu).

Po Asimovome kiraetu riječ rabbena je u vokativu, a ba'id $\mathrm{u}$ imperativu. U tom smislu je i prijevod: "Gospodaru naš, učini dugim udaljenosti (...)

Asad, pozivajući se na Zamahšerija, Begavija i Taberija, koji se pozivaju na najranije kur'anske komentatore, daje novo čitanje: rabbuna (nominativ) i be'ade (indikativ) pa je navedeni prijevod takav kakav jeste: „Po mome mišljenju, ovo čitanje je mnogo primjerenije pošto ono (kao što je istakao Zamahšeri) izražava zakašnjelo kajanje i žaljenje naroda Sabe zbog opustošenja njihove zemlje, egzodusa velikih skupina stanovništva i napuštanja mnogih gradova i sela na velikim karavanskim putovima.“31

Evo još nekoliko primjera koji pokazuju da je Asad koristio kiraetske različite izgovore u svojoj Poruci Kur'ana:

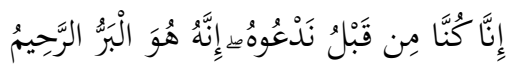

Uistinu, mi smo zazivali (samo) Njega prije ovoga (i sada nam je On pokazao) da je samo On istinski dobrostiv, Darivatelj milosti! (Et-Tur, 28)

\footnotetext{
${ }^{30}$ Asad, Poruka Kur'ana, 689 (50).

${ }^{31}$ Asad, Poruka Kur'ana, 656 (27).
} 
Kao što možemo primijetiti, Asad je u svoj prijevod ubacio interpolaciju ,i sada nam je On pokazao“ pod kojom se misli „kroz naše vlastito, aktualno iskustvo“. Takva interpolacija se dobiva na osnovu čitanja riječi iz navedenog ajeta kao ennehu (,da je On“), što je u skladu s medinskom školom, ${ }^{32}$ nasuprot konvencionalnijem čitanju iz Kufe i Basre kao innehu (,uistinu, On je“): „Ja sam za svoj prijevod izabrao prvo čitanje pošto ono ukazuje na neodoljiv, izravan uvid koji će biti

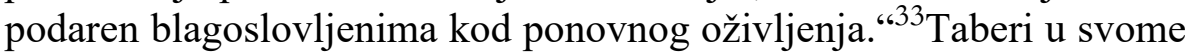

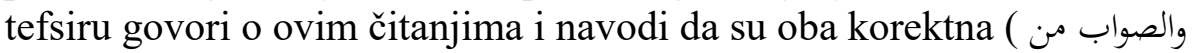
(القول في ذلك، أفما قراءتان معروفتان، فبأيتهما قرأ القارىء فمصيب

Slijedeći primjer je:

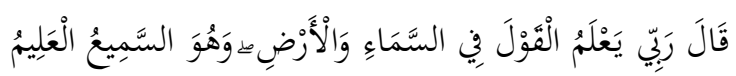

Reci: , Uzdržavatelj moj zna sve što se govori na nebu i na Zemlji; samo On sve čuje, sve zna. " (El-Enbija, 4)

Asad je početak ajeta preveo imperativom qul kako se čitalo u Medini, Basri i Kufi ( u Mekki se čitalo kao qale - „Poslanik reče“). On smatra da je u najranijim kopijama Kur'ana pravopis očigledno bio ograničen, u ovome slučaju na konsonante $q$ - $l$. Odatle mogućnost čitanja kao qul ili kao qale: „Među klasičnim mufessirima, Begawi i Bejdawi izričito koriste oblik qul, dok Zamahšerijeva kratka primjedba da je 'to isto tako izgovarano i kao qale' izgleda da ukazuje na njegovo davanje prednosti imperativu qul.“34

Taberi u svome tefsiru ističe da oba ova čitanja imaju isto značenje pa su, prema tome, jednako valjana ,jer, kad je Bog zapovjedio Muhammedu da to kaže, on je to (nesumnjivo) rekao... Zato, kako god da se čita ova riječ, čitalac je korektan (musibus-savab) u svome

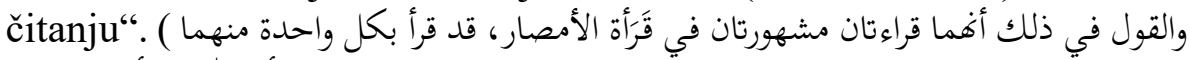

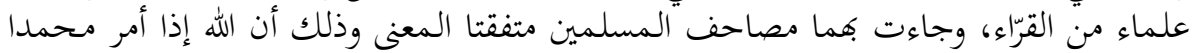

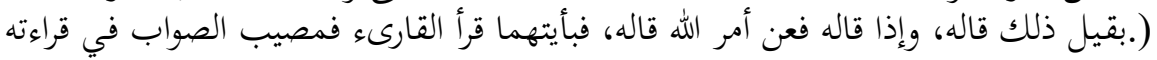

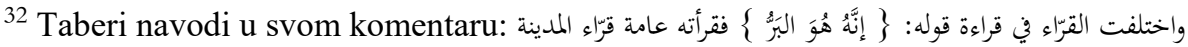

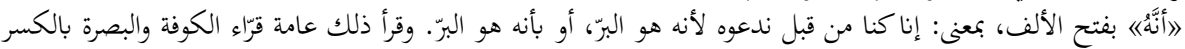
على الابتداء

${ }^{33}$ Asad, Poruka Kur'ana, 817 (16).

${ }^{34}$ Isto, 482 (5).
} 
Asad je i za 24. ajet sure Ez-Zuhruf naveo da je početak ajeta vokaliziran kao imperativ ( $q u l$ - „,kaži“). Međutim, kod ovog ajeta se opredijelio za Hafsov kiraet u kojem se čita qale (,on reče“, a pošto je ponovljena pojava, onda: „on bi rekao“). Asad se za Hafsov kiraet opredijelio i kod 18. ajeta sure El-Hadid:

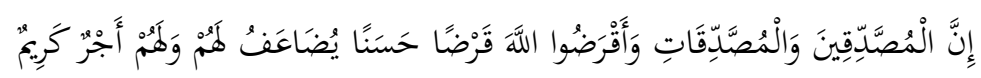

Uistinu, muškarci i žene koji ovu Istinu prihvate kao istinitu, i koji (na taj način) ponude Allahu lijep zajam, - njima će biti obilno vraćeno: imat će plemenitu nagradu (u životu na onome svijetu.

U ovom kiraetu se pojavljuju dva oblika jedne imenice: mussaddiqin i mussaddiqat. U Asadovom se komentaru navodi da to može značiti i „muškarci i žene koji daju iz samilosti“", zavisno od vokalizacije konsonanata sad i dal: ,S obzirom na ono što slijedi, smisao dat u mome prijevodu izgleda da ima prednost (a Zamahšeri naglašava da zaista ima). ${ }^{\text {‘35 }}$

\section{Literatura}

1. Asad, Muhammed, Poruka Kur'ana, prev. Hilmo Ćerimović, Sarajevo: el-Kalem, 2004.

2. , Sahih al-Bukhari: The Early Years of Islam, Lahori, 1938.

3. At-Tabarī, Džāmi' al-bayān 'an ta'wīl āyi 'l-Qur'ān, XXX, Dār alfikr, Bayrūt, 1995.

4. Az-Zarkašī, Al-Burhān fì 'ulūm al-Qur'ān, Dār al-dž̄̌l, Bayrūt, 1988.

5. Az-Zamahšeri, Tefsiru l-Keššafi, Daru ma'rifetin, Bayrut, 2005.

6. M. M. El-A'zami, Historija kur'anskog teksta, prev. Džemaludin Latić, Sarajevo: El-Kalem, 2014.

7. Dževad Šošić, Kiraeti u tefsiru imama Kurtubija, Sarajevo: ElKalem i FIN, 2014.

35 Asad, Poruka Kur'ana, 848 (26).

Ako obratimo pažnju na Zamahšerijev Keššaf, vidimo da je Asad u cijelosti slijedio

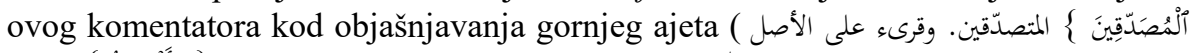

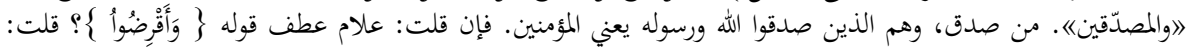

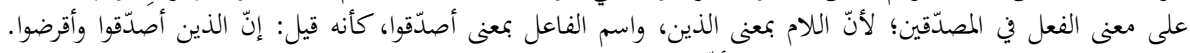

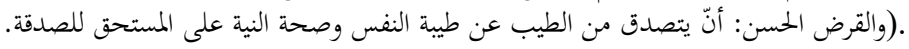


Rifet Šahinović, PhD

\section{QIRA'AT/WAYS OF READING QUR'AN}

Abstract

Muhammad Asad (Leopold Weiss, 1900-1990.), a revert to Islam, is one of the many thinkers which greatly influenced Western Muslims opinion during the second half of the XX century. Among others, the most important Asad's work is a translation and commentary of the Qur'an in English entitled 'The Message of the Qur'an'. In the first part of this work we deal with the question of importance of knowledge of Qira'at in Islamic sciences. Another part of our work illustrates Asad's reliance on Qira'at in his translating solutions of Qur'anic verses.

Keywords: Qira'at, Muhammad Asad, Message of the Qur'an, translation solutions 


$$
\text { الدكتور المساعد رفعت شاهينوفيتش' }
$$

\section{القراءات القرآنية}

\section{الخلاصية}

يعتبر محمد أسد (ليوبولد فايس سابقاً . . 19-ـ9919)، العائد إلى الإسلام، واحداً

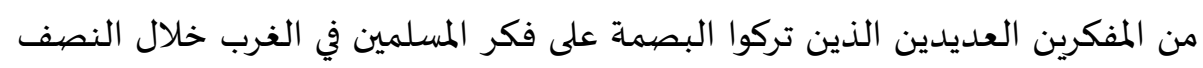

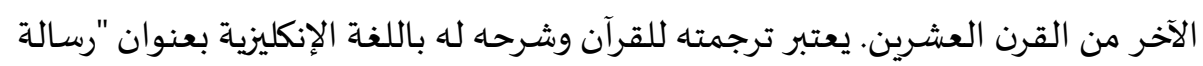

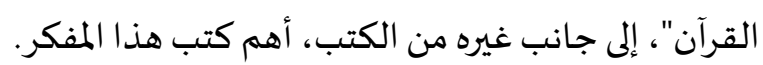

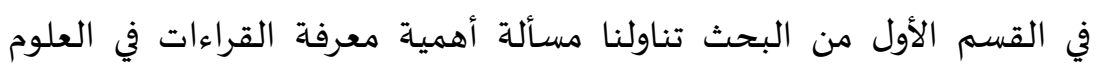

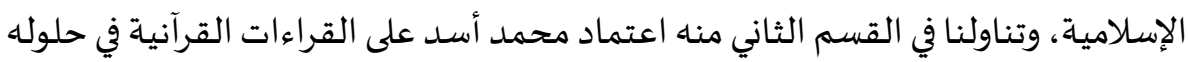
الترجمية للآيات القرآنية. الكلمات الرئيسـة: القراءات، محمد أسـد، رسالة القرآن، الحلول الترجمية

' الأستاذ في كلية التربية الإسلامية في بيهاتش 